\title{
High Pressure Oxidation of Dimethoxymethane
}

\author{
Lorena Marrodán, Eduardo Royo, Ángela Millera, Rafael Bilbao, and María U. Alzueta* \\ Aragón Institute of Engineering Research (I3A). Department of Chemical and Environmental \\ Engineering. University of Zaragoza. 50018 Zaragoza. Spain \\ * uxue@unizar.es
}

\begin{abstract}
The oxidation of dimethoxymethane (DMM) has been studied under a wide range of temperatures (373-1073 K), pressures (20-60 bar) and air excess ratios $(\lambda=0.7,1$ and 20$)$, from both experimental and modeling points of view. Experimental results have been interpreted and analyzed in terms of a detailed gas-phase chemical kinetic mechanism for describing the DMM oxidation. The results show that the DMM oxidation regime for 20,40 and 60 bar is very similar for both reducing and stoichiometric conditions. For oxidizing conditions, a plateau in the DMM, $\mathrm{CO}$ and $\mathrm{CO}_{2}$ concentration profiles as a function of the temperature can be observed. This zone seems to be associated to the peroxy intermediate, $\mathrm{CH}_{3} \mathrm{OCH}_{2} \mathrm{O}_{2}$, whose formation and consumption reactions appear to be important for the description of DMM conversion under high pressure and high oxygen concentration conditions.
\end{abstract}

KEYWORDS: dimethoxymethane, high-pressure, oxidation, kinetic model. 


\section{Introduction}

Diesel engines are used for transportation because of their high fuel efficiency. However, they highly contribute to nitrogen oxides $\left(\mathrm{NO}_{\mathrm{x}}\right)$ and particulate matter $(\mathrm{PM})$ emissions, which are difficult to reduce simultaneously in conventional diesel engines $\left(\mathrm{NO}_{\mathrm{x}}\right.$ formation is favored under fuel-lean conditions, whereas PM is formed when there is a lack of oxygen). The addition of oxygenated compounds to diesel fuel can effectively reduce these emissions [1-4]. For instance, the reduction of smoke has been reported to be strongly related to the oxygen content of blends [5] without increasing the $\mathrm{NO}_{\mathrm{x}}$ and engine thermal efficiency.

Dimethoxymethane (methylal or $\mathrm{DMM}, \mathrm{CH}_{3} \mathrm{OCH}_{2} \mathrm{OCH}_{3}$ ) is a diether considered to be a potential fuel additive. In comparison to the simplest ether, dimethyl ether (DME), that has been widely proposed and tested for using with diesel fuel as a means of reducing exhaust emissions [6-7], DMM has a higher quantity of oxygen, lower vapor pressure, and better solubility with diesel fuel. Several studies have analyzed the effect of adding DMM to base diesel on emissions of compression ignition engines or direct injection engines (e. g. Ren et al. 2006 [8]) and, in general, diesel-DMM blends increase engine performance and decrease exhaust emissions.

Huang et al. [9] studied the combustion and the emissions of a compression ignition engine fuelled with blends of diesel-DMM. They found that a remarkable reduction in the exhaust $\mathrm{CO}$ and smoke can be achieved when operating with diesel-DMM blends, and a simultaneous reduction in both $\mathrm{NO}_{\mathrm{x}}$ and smoke can be obtained with large DMM additions. Sathiyagnanam and Saravanan [10] also analyzed the effects of DMM addition to diesel, and obtained an appreciable reduction of emissions such as smoke density, particulate matter, and a marginal increase in the performance when compared with the normal diesel run. Chen et al. [11] developed an experimental and modeling study of the effects of adding oxygenated fuels to 
premixed n-heptane flames and found that, as oxygenated fuels were added, mole fractions of most $\mathrm{C}_{1}-\mathrm{C}_{5}$ hydrocarbon intermediates were significantly reduced together with an apparent decrease of benzene amount.

Although a great volume of experiments have been conducted to determine the effects of diesel-DMM blends in the CO and smoke emissions, few studies have been focused on the combustion characteristics of pure DMM fuel at high temperatures [12] and even less at high pressures.

Daly et al. [13] investigated the oxidation of DMM in a jet-stirred reactor at a pressure of 5.07 bar, high temperatures of $800-1200 \mathrm{~K}$ and equivalence ratios of $0.444(\lambda=2.25), 0.889$ $(\lambda=1.13)$ and $1.778(\lambda=0.56)$, and proposed a sub-mechanism of 50 reactions relevant to describe the combustion of DMM, including a significant number of estimated rate constants. Recently, Dias et al. [14] have studied lean and rich premixed DMM flames to build a submechanism taking into account the formation and the consumption of oxygenated species involved in DMM oxidation. They were able to build a new mechanism containing 480 elementary reactions and involving 90 chemical species, by using kinetic data from the literature about DMM, mainly drawn from Daly et al. [13], in order to simulate the DMM flames. Whatever the availability of oxygen in the flow, they established two main DMM conversion routes, with the first one being the fastest:

$\mathrm{CH}_{3} \mathrm{OCH}_{2} \mathrm{OCH}_{3} \rightarrow \mathrm{CH}_{3} \mathrm{OCH}_{2} \mathrm{OCH}_{2} \rightarrow \mathrm{CH}_{3} \mathrm{OCH}_{2} \rightarrow \mathrm{CH}_{2} \mathrm{O} \quad$ (route 1)

$\mathrm{CH}_{3} \mathrm{OCH}_{2} \mathrm{OCH}_{3} \rightarrow \mathrm{CH}_{3} \mathrm{OCHOCH}_{3} \rightarrow \mathrm{CH}_{3} \mathrm{OCHO} \rightarrow \mathrm{CH}_{3} \mathrm{OCO} \rightarrow \mathrm{CH}_{3} \mathrm{O} \rightarrow \mathrm{CH}_{2} \mathrm{O}$ (route 2).

In this context, a study on DMM oxidation carried out under well controlled tubular flow reactor conditions at atmospheric pressure, from pyrolysis to high oxidizing conditions, from both experimental and modeling points of view, was previously developed by our research group [15]. The results obtained indicate that the initial oxygen concentration slightly 
influences the consumption of DMM. In general, a good agreement between experimental and modeling data was obtained and, accordingly, the final mechanism compiled in that work has been taken as the initial mechanism in the present work.

Therefore, the purpose of the present work is to carry out an experimental study of DMM conversion at high-pressure covering a large range of temperature, pressure, and different stoichiometries, together with the validation of a kinetic mechanism under high-pressure conditions, which would be of interest for diesel applications. Specifically, experiments have been performed under well-controlled flow reactor conditions, in the $373-1073 \mathrm{~K}$ temperature range and for different high-pressures (20, 40 and 60 bar). Under these conditions, the oxygen concentration was varied from 1960 to 56000 ppm resulting in different air excess ratios $(\lambda)$, ranging from 0.7 to 20 . Additionally, a modeling study to describe the oxidation of DMM was performed using the gas-phase detailed chemical kinetic mechanism of our previous work [15], which has been updated in the present work to account for working at high pressures.

\section{Experimental}

The experimental installation used in the present work is described in detail elsewhere [16] and only a brief description is given here. It consists basically of a gas feeding system, a reaction system and a gas analysis system.

Gases are supplied from gas cylinders through mass flow controllers. A concentration of approximately $700 \mathrm{ppm}$ of DMM is introduced in all the experiments. The amount of $\mathrm{O}_{2}$ used has been varied between 1960 and $56000 \mathrm{ppm}$, and is related to the air excess ratio $(\lambda)$, defined as the inlet oxygen concentration divided by the stoichiometric oxygen. Therefore, values of $\lambda$ lower than 1 refer to fuel rich conditions, and $\lambda$ values larger than 1 , refer to fuel 
lean conditions. Nitrogen is used to balance, resulting in a constant flow rate of 1000 (STP) $\mathrm{mL} / \mathrm{min}$.

The DMM oxidation takes place in a quartz flow reactor (inner diameter of $6 \mathrm{~mm}$ and 1500 $\mathrm{mm}$ in length) that is enclosed in a stainless steel tube that acts as a pressure shell. Nitrogen is delivered to the shell side of the reactor by a pressure control system, to obtain a pressure similar to that inside the reactor avoiding this way the stress in the reactor.

The reactor tube is placed horizontally in a three-zone electrically heated furnace, ensuring a uniform temperature profile within $\pm 10 \mathrm{~K}$ throughout the isothermal reaction zone $(56 \mathrm{~cm})$. The gas residence time, $\mathrm{t}_{\mathrm{r}}$, in the isothermal zone, is a function of the reaction temperature and pressure, $\mathrm{t}_{\mathrm{r}}(\mathrm{s})=261 * \mathrm{P}($ bar $) / \mathrm{T}(\mathrm{K})$.

Downstream the reactor, the pressure is reduced to atmospheric level. Before analysis, the product gases pass through a condenser and a filter to ensure gas cleaning. The outlet gas composition is measured using a gas micro chromatograph (Agilent 3000), which is able to detect and measure DMM and the main products of its oxidation: methyl formate $\left(\mathrm{CH}_{3} \mathrm{OCHO}\right)$, formaldehyde $\left(\mathrm{CH}_{2} \mathrm{O}\right), \mathrm{CO}, \mathrm{CO}_{2}$ and $\mathrm{CH}_{4}$. No other products were detected in a noticeable amount. The uncertainty of measurements is estimated as $\pm 5 \%$. To evaluate the goodness of the experiments, the atomic carbon balance was checked in all the experiments and resulted to close always near $100 \%$.

The experiments were carried out at different pressures (20, 40 and 60 bar) and in the 373$1073 \mathrm{~K}$ temperature range. Table 1 lists the conditions of the experiments. 


\section{Modeling}

The experimental results have been analyzed in terms of a detailed gas-phase chemical kinetic mechanism for describing the oxidation of DMM. The model taken as starting point was the kinetic mechanism compiled in the previously appointed work about the DMM oxidation at atmospheric pressure by our research group [15]. This one was built by adding different reaction subsets found in the literature to the model developed by Glarborg et al. [17] updated and extended later $[18,19]$. The additional reaction subsets included for the different expected or involved compounds of relevance for the present experiments were: dimethyl ether (DME) [20], ethanol [21], acetylene [22], and methyl formate (MF) [23]. The last one subset was revised by our group [16] to account for high-pressure conditions in the methyl formate oxidation, which are similar to those of the present work. For DMM, the Dias et al. reaction subset [14] developed for atmospheric pressure was also included. Thermodynamic data for the involved species are taken from the same sources as the cited mechanisms.

The model used in the previous work [15] has been modified in the present work to account also for the high-pressure conditions studied in the DMM oxidation. The changes made to the mechanism are listed in Table 2 and will be described below. The final mechanism involves 726 reactions and 142 species.

Thermal decomposition of DMM is an important initiation step, and can occur through DMM breaking, reactions 1 and 2, or by losing a primary or a secondary hydrogen atom, reactions 3 and 4 respectively. The constants for these reactions were kept, without any modification, from the work of Dias et al. [14], originally proposed by Daly et al. [13].

For reaction 1 , the value of $2.62 \times 10^{16} \exp (-41369 / \mathrm{T}) \mathrm{cm}^{3} \mathrm{~mol}^{-1} \mathrm{~s}^{-1}$ for the rate constant was taken from the estimation made by Dagaut et al. [24] for DME, from a fit of the available NIST [25] data. For reaction 2, the value for the rate constant, $2.51 \times 10^{15} \exp (-38651 / \mathrm{T}) \mathrm{cm}^{3}$ 
$\mathrm{mol}^{-1} \mathrm{~s}^{-1}$, estimated by Foucaut and Martin by analogy with diethylether [26] was taken, and for reaction 3 , the kinetic parameters $\left(4.35 \times 10^{16} \exp (-50327 / \mathrm{T}) \mathrm{cm}^{3} \mathrm{~mol}^{-1} \mathrm{~s}^{-1}\right)$ were taken from the estimation for the similar reaction involving ethane [27]. Finally, for the loss of a secondary hydrogen atom from DMM, reaction 4, Dean [27] estimated the rate constant by analogy with the rate constant for the loss of a secondary atom of hydrogen from propane, with a value of $6.31 \times 10^{15} \exp (-47660 / \mathrm{T}) \mathrm{cm}^{3} \mathrm{~mol}^{-1} \mathrm{~s}^{-1}$.

$\mathrm{CH}_{3} \mathrm{OCH}_{2} \mathrm{OCH}_{3} \rightleftharpoons \mathrm{CH}_{3}+\mathrm{CH}_{3} \mathrm{OCH}_{2} \mathrm{O}$

$\mathrm{CH}_{3} \mathrm{OCH}_{2} \mathrm{OCH}_{3} \rightleftharpoons \mathrm{CH}_{3} \mathrm{O}+\mathrm{CH}_{3} \mathrm{OCH}_{2}$

$\mathrm{CH}_{3} \mathrm{OCH}_{2} \mathrm{OCH}_{3} \rightleftharpoons \mathrm{CH}_{3} \mathrm{OCH}_{2} \mathrm{OCH}_{2}+\mathrm{H}$

$\mathrm{CH}_{3} \mathrm{OCH}_{2} \mathrm{OCH}_{3} \rightleftharpoons \mathrm{CH}_{3} \mathrm{OCHOCH}_{3}+\mathrm{H}$

An important pathway for DMM consumption includes hydrogen abstraction reactions by the $\mathrm{O} / \mathrm{H}$ radical pool. For the reactions with $\mathrm{H}$ (reactions 5 and 6 ), the rate expressions were taken from the DMM subset proposed by Dias et al. [14], which were, a priori, taken from Daly et al. [13]. The rate constant of reaction 5 was taken as that for the reaction between DME and a hydrogen atom [28], that is $9.70 \times 10^{13} \exp (-3125 / \mathrm{T}) \mathrm{cm}^{3} \mathrm{~mol}^{-1} \mathrm{~s}^{-1}$. For reaction 6 , the $7.40 \mathrm{x}$ $10^{12} \exp (-1631 / \mathrm{T}) \mathrm{cm}^{3} \mathrm{~mol}^{-1} \mathrm{~s}^{-1}$ rate constant was based on the abstraction of a secondary hydrogen atom from diethylether [29]. Although, Dias et al. [14] included an A-factor for this reaction divided by 2 in their final mechanism, we adopted the value originally proposed by Daly et al. [13], which is $7.40 \times 10^{12} \mathrm{~cm}^{3} \mathrm{~mol}^{-1} \mathrm{~s}^{-1}$.

$\mathrm{CH}_{3} \mathrm{OCH}_{2} \mathrm{OCH}_{3}+\mathrm{H} \rightleftharpoons \mathrm{CH}_{3} \mathrm{OCH}_{2} \mathrm{OCH}_{2}+\mathrm{H}_{2}$

$\mathrm{CH}_{3} \mathrm{OCH}_{2} \mathrm{OCH}_{3}+\mathrm{H} \rightleftharpoons \mathrm{CH}_{3} \mathrm{OCHOCH}_{3}+\mathrm{H}_{2}$ 
In the case of the reactions between DMM and $\mathrm{O}$ radicals (reactions 7 and 8), their rate constants were taken from the DMM subset proposed by Dias et al. [14] without any modification, previously adopted from [30], by analogy with $\mathrm{CH}_{3} \mathrm{OCH}_{2}$ for reaction 7, and by analogy with diethylether, for reaction 8 .

$\mathrm{CH}_{3} \mathrm{OCH}_{2} \mathrm{OCH}_{3}+\mathrm{O} \rightleftharpoons \mathrm{CH}_{3} \mathrm{OCH}_{2} \mathrm{OCH}_{2}+\mathrm{OH}$

$\mathrm{CH}_{3} \mathrm{OCH}_{2} \mathrm{OCH}_{3}+\mathrm{O} \rightleftharpoons \mathrm{CH}_{3} \mathrm{OCHOCH}_{3}+\mathrm{OH}$

Reaction with hydroxyl radicals $(\mathrm{OH})$ is an important step in the oxidation of organic compounds in combustion systems [31]. Although it will be discussed later through the analysis of the different reaction pathways, the main consumption of DMM occurs through $\mathrm{H}$ abstraction reactions by $\mathrm{OH}$ to form $\mathrm{CH}_{3} \mathrm{OCH}_{2} \mathrm{OCH}_{2}$ and $\mathrm{CH}_{3} \mathrm{OCHOCH}_{3}$ radicals (reactions 9 and 10). The kinetic parameters of these reactions have been modified from the previous work [15].

$\mathrm{CH}_{3} \mathrm{OCH}_{2} \mathrm{OCH}_{3}+\mathrm{OH} \rightleftharpoons \mathrm{CH}_{3} \mathrm{OCH}_{2} \mathrm{OCH}_{2}+\mathrm{H}_{2} \mathrm{O}$

$\mathrm{CH}_{3} \mathrm{OCH}_{2} \mathrm{OCH}_{3}+\mathrm{OH} \rightleftharpoons \mathrm{CH}_{3} \mathrm{OCHOCH}_{3}+\mathrm{H}_{2} \mathrm{O}$

In the Dias et al. DMM reaction subset [14], the rate constant of these reactions is estimated by analogy with the reaction $\mathrm{CH}_{3} \mathrm{OCH}_{3}+\mathrm{OH}=\mathrm{CH}_{3} \mathrm{OCH}_{2}+\mathrm{H}_{2} \mathrm{O}$ from DeMore and Bayes [32], with a proposed value of $9.10 \times 10^{12} \exp (-496 / \mathrm{T}) \mathrm{cm}^{3} \mathrm{~mol}^{-1} \mathrm{~s}^{-1}$, determined experimentally in the 263-361 K temperature range. Arif et al. [31] determined a rate constant of $6.32 \times 10^{6} \mathrm{~T}^{2} \exp (327 / \mathrm{T}) \mathrm{cm}^{3} \mathrm{~mol}^{-1} \mathrm{~s}^{-1}$, in the 295-650 K temperature range, which is adopted in this study, also used in the work of Alzueta et al. [20], and that is in agreement with the high-temperature (923-1423 K) determination of Cook et al. [33]. With this value, the latest authors achieved a good fit for both the low and the high temperature measurements. 
The prevalence of $\mathrm{HO}_{2}$ radicals under high pressure, and preferably lean conditions, should make them to play an important role under the conditions of the present work. Reactions involving $\mathrm{DMM}$ and $\mathrm{HO}_{2}$ radicals (reactions 11 and 12) were not included in the initial reaction subset of Dias et al. [14], and we have included them in the present work,

$$
\mathrm{CH}_{3} \mathrm{OCH}_{2} \mathrm{OCH}_{3}+\mathrm{HO}_{2} \rightleftharpoons \mathrm{CH}_{3} \mathrm{OCH}_{2} \mathrm{OCH}_{2}+\mathrm{H}_{2} \mathrm{O}_{2}
$$

$$
\mathrm{CH}_{3} \mathrm{OCH}_{2} \mathrm{OCH}_{3}+\mathrm{HO}_{2} \rightleftharpoons \mathrm{CH}_{3} \mathrm{OCHOCH}_{3}+\mathrm{H}_{2} \mathrm{O}_{2}
$$

The rate constants for reactions 11 and 12 have not been measured to our knowledge and, therefore, there is some degree of uncertainty in their absolute values. For reaction 11, the rate parameters have been taken by analogy of the dimethyl ether and $\mathrm{HO}_{2}$ reaction, following the same procedure described by Daly et al. [13], and likewise taking the value, $1.00 \times 10^{13} \exp (-$ $8900 / \mathrm{T}) \mathrm{cm}^{3} \mathrm{~mol}^{-1} \mathrm{~s}^{-1}$, from the work of Curran et al. [34]. The rate constant for abstraction of a secondary hydrogen atom (reaction 12) was estimated by Daly et al. [13] from the value for reaction 11 , with the A factor divided by a factor of 6 . These authors stated that DMM has six primary hydrogen atoms and only two secondary ones, so the probability of attack will therefore be lower for the attack on the $\mathrm{CH}_{2}$ groups than on the $\mathrm{CH}_{3}$ groups. Also, the proximity of two oxygen atoms to the central carbon atom of the molecule will make the hydrogen atoms attached to it more labile than those belonging to the methyl groups. As a result, the activation energy for reaction 12 should be lower than for reaction 11 . Thus, a rate constant value of $2.00 \times 10^{12} \exp (-7698 / \mathrm{T}) \mathrm{cm}^{3} \mathrm{~mol}^{-1} \mathrm{~s}^{-1}$ was proposed for reaction 12 [13], which is adopted in the present mechanism.

The subset proposed by Dias et al. [14] includes reactions involving DMM with molecular oxygen (reaction 13 and 14) and their corresponding rate constants, adopted here with no modification from the work of Daly et al. [13], were both estimated by analogy with the reaction of DME with oxygen. Therefore, the rate parameters for reaction 13 are the same as 
those considered by Dagaut et al. [24] (although for reaction 13, the values used by Dias et al. [14] are not the corresponding ones to the source specified, as also was indicated in the case of reaction 6), and the parameters for reaction 14 were estimated by Daly et al. [13] as previously done in the case of reactions involving $\mathrm{HO}_{2}$ radicals.

$\mathrm{CH}_{3} \mathrm{OCH}_{2} \mathrm{OCH}_{3}+\mathrm{O}_{2} \rightleftharpoons \mathrm{CH}_{3} \mathrm{OCH}_{2} \mathrm{OCH}_{2}+\mathrm{HO}_{2}$

$\mathrm{CH}_{3} \mathrm{OCH}_{2} \mathrm{OCH}_{3}+\mathrm{O}_{2} \rightleftharpoons \mathrm{CH}_{3} \mathrm{OCHOCH}_{3}+\mathrm{HO}_{2}$

Although the reactions of $\mathrm{CH}_{3} \mathrm{OCH}_{2} \mathrm{OCH}_{2}$ and $\mathrm{CH}_{3} \mathrm{OCHOCH}_{3}$ radicals with $\mathrm{O}_{2}$ (reactions 15 and 16) and $\mathrm{HO}_{2}$ (reactions 17 and 18) were omitted in previous DMM mechanisms [14, 15, 34], they can play an important role in the oxidation of DMM, particularly under high pressure and high oxygen concentration conditions and, therefore, these reactions have been included in our final mechanism.

$\mathrm{CH}_{3} \mathrm{OCH}_{2} \mathrm{OCH}_{2}+\mathrm{O}_{2} \rightleftharpoons \mathrm{CH}_{2} \mathrm{O}+\mathrm{CH}_{3} \mathrm{OCHO}+\mathrm{OH}$

$\mathrm{CH}_{3} \mathrm{OCHOCH} \mathrm{H}_{3}+\mathrm{O}_{2} \rightleftharpoons \mathrm{CH}_{2} \mathrm{O}+\mathrm{CH}_{3} \mathrm{OCHO}+\mathrm{OH}$

$\mathrm{CH}_{3} \mathrm{OCH}_{2} \mathrm{OCH}_{2}+\mathrm{HO}_{2} \rightleftharpoons \mathrm{CH}_{2} \mathrm{O}+\mathrm{CH}_{3} \mathrm{OCH}_{2} \mathrm{O}+\mathrm{OH}$

$\mathrm{CH}_{3} \mathrm{OCHOCH}{ }_{3}+\mathrm{HO}_{2} \rightleftharpoons \mathrm{CH}_{3} \mathrm{OCHO}+\mathrm{CH}_{3} \mathrm{O}+\mathrm{OH}$

For reactions 15 and 16, the rate constants have been estimated establishing an analogy with the reaction of methoxy-methyl radical $\left(\mathrm{CH}_{3} \mathrm{OCH}_{2}\right.$, generated in the dimethyl ether thermal decomposition) and oxygen molecular, as previously done by Daly et al. [13]. In that case, they chose the kinetic parameters given by Dagaut et al. [24]; namely, $1.70 \times 10^{10} \exp (337 / \mathrm{T})$ $\mathrm{cm}^{3} \mathrm{~mol}^{-1} \mathrm{~s}^{-1}$, which were estimated based on $\mathrm{C}_{2} \mathrm{H}_{5}+\mathrm{O}_{2}$ kinetics. However, here, we have chosen a value of the $\mathrm{CH}_{3} \mathrm{OCH}_{2}+\mathrm{O}_{2}$ rate constant of $2.50 \times 10^{11} \exp (850 / \mathrm{T}) \mathrm{cm}^{3} \mathrm{~mol}^{-1} \mathrm{~s}^{-1}$, obtained by Alzueta et al. [20] from averaging three room-temperature determinations [35- 
37], and adopting the temperature dependence reported in Hoyermann and Nacke [37], which is significantly faster than that proposed in the mechanism of Dagaut et al. [24].

In the same way, the analogy used before in the case of reactions with molecular oxygen $\left(\mathrm{CH}_{3} \mathrm{OCH}_{2}+\mathrm{O}_{2}\right)$ has been applied to obtain the rate constants of reactions 17 and 18 , i.e. $\mathrm{CH}_{3} \mathrm{OCH}_{2}+\mathrm{HO}_{2}$. Not much information has been found related to these reactions, and the value proposed by Daly et al. [13], based on estimations made by Dagaut et al. [24] has been chosen. This value is, for reaction $17,3.00 \times 10^{11} \mathrm{~cm}^{3} \mathrm{~mol}^{-1} \mathrm{~s}^{-1}$ and, for reaction 18 they increased this value to $1.00 \times 10^{12} \mathrm{~cm}^{3} \mathrm{~mol}^{-1} \mathrm{~s}^{-1}$.

Curran et al. [34] stated that the pathway involving peroxy intermediates may be important at low temperatures (below approximately $900 \mathrm{~K}$ ) and pressures higher than 10 bar, because the bimolecular addition of methoxy-methyl radical to $\mathrm{O}_{2}$ has a lower activation energy barrier than the $\beta$-scission to yield $\mathrm{CH}_{2} \mathrm{O}$ and $\mathrm{CH}_{3}$, the two main pathways that methoxy-methyl radicals can undergo. At atmospheric pressure (e.g. Alzueta et al. [20]), the formation of methoxy methyl-peroxy intermediate is not predicted to be significant, except for a minor contribution for very lean stoichiometries.

Under the conditions studied in this work, high pressures (20, 40 and 60 bar) and fuel lean conditions $(\lambda=20)$, the reactions forming peroxy species (reactions 19 and 20) may have an important impact on the oxidation chemistry of DMM and, therefore, these reactions have been included in our final mechanism.

$\mathrm{CH}_{3} \mathrm{OCH}_{2} \mathrm{OCH}_{2}+\mathrm{O}_{2} \rightleftharpoons \mathrm{CH}_{3} \mathrm{OCH}_{2} \mathrm{O}_{2}+\mathrm{CH}_{2} \mathrm{O}$

$\mathrm{CH}_{3} \mathrm{OCH}_{2} \mathrm{OCH}_{2}+\mathrm{HO}_{2} \rightleftharpoons \mathrm{CH}_{3} \mathrm{OCH}_{2} \mathrm{O}_{2}+\mathrm{CH}_{2} \mathrm{OH}$

For reaction 19, the kinetic parameters have been estimated by analogy with the reaction of methoxy-methyl radical with molecular oxygen. The $6.40 \times 10^{12} \exp (-45.80 / \mathrm{T}) \mathrm{cm}^{3} \mathrm{~mol}^{-1} \mathrm{~s}^{-1}$ 
value for $\mathrm{CH}_{3} \mathrm{OCH}_{2}+\mathrm{O}_{2}$ was considered in an earlier mechanism by our group [20]. For reaction 20, no values of kinetic parameters were found, and we have considered initially a reaction rate of $1.0 \times 10^{12} \mathrm{~cm}^{3} \mathrm{~mol}^{-1} \mathrm{~s}^{-1}$. The results of sensitivity analysis, shown later, indicate no significant impact of this estimation.

Model calculations have been performed using both SENKIN [38] from the CHEMKIN II software package [39] and CHEMKIN-PRO [40], considering pressure constant in the reaction zone and the corresponding temperature profile. An example of temperature profiles inside the reactor can be found in [16]. The full mechanism listing and thermochemistry used can be found as Supporting Information.

\section{Results and discussion}

In this work, a study of the oxidation of DMM at different pressures (20, 40 and 60 bar), and in the $373-1073 \mathrm{~K}$ temperature range, has been carried out. In addition to temperature and pressure, the influence of stoichiometry $(\lambda=0.7,1$ and 20) on the oxidation process has also been analyzed. As mentioned, the experimental results have been interpreted in terms of the detailed kinetic mechanism previously described.

Figures 1 and 2 show the influence of the temperature and pressure for specific air excess ratios, $\lambda=0.7$ and $\lambda=1$, respectively, on the concentration of DMM and the formation of the main products of its oxidation at high pressures: $\mathrm{CH}_{2} \mathrm{O}, \mathrm{CO}_{2}, \mathrm{CO}, \mathrm{CH}_{3} \mathrm{OCHO}$ and $\mathrm{CH}_{4}$. No other products have been detected in an appreciable amount. At atmospheric pressure, other products such as $\mathrm{C}_{2} \mathrm{H}_{4}, \mathrm{C}_{2} \mathrm{H}_{6}$ and $\mathrm{C}_{2} \mathrm{H}_{2}$, were detected through micro GC analysis in amounts lower than $100 \mathrm{ppm}$, and especially for reducing $(\lambda=0.7)$, very reducing $(\lambda=0.4)$ and pyrolysis $(\lambda=0)$ conditions [15]. Methanol is highly formed at atmospheric pressure [15], while at 
higher pressures (20-60 bar) formaldehyde is predominant, although the distinction between methanol and formaldehyde with micro-GC techniques sometimes is quite tricky.

Both Figures 1 and 2 compare experimental (symbols) and model calculation (lines) results. Working at 20, 40 or 60 bar, does not have a big effect neither on the oxidation of DMM nor on the formation of the main products. The suggested model predicts the general trend of the different concentration profiles, although there are some discrepancies between experimental and simulation results. These discrepancies are especially remarkable for $\lambda=0.7$, where the $\mathrm{CO}_{2}$ concentration values at high temperatures are underestimated, whereas the $\mathrm{CO}$ values are overestimated. It is difficult to isolate the origin of those discrepancies, and may be attributed to the uncertainty in the conversion of intermediates. This fact is not observed for the other values of $\lambda$ considered. The oxygen concentration in the reactant mixture slightly influences the conversion of DMM, similar to what has been observed in the oxidation behavior of other oxygenated compounds such as DME [20] or MF [16].

Figure 3 shows a reaction path diagram for DMM oxidation through a reaction rate analysis with the mechanism used in the present work. For the conditions analyzed in the present work, the main consumption of DMM is through $\mathrm{H}$ abstraction reactions by the hydroxyl radical $(\mathrm{OH})$ to form $\mathrm{CH}_{3} \mathrm{OCH}_{2} \mathrm{OCH}_{2}$ and $\mathrm{CH}_{3} \mathrm{OCHOCH}_{3}$ radicals (reactions 9 and 10), which is in agreement with other previous works [13]. Both reactions have a relative importance of $38 \%$. This value increases up to near $50 \%$ under oxidizing conditions.

$$
\begin{aligned}
& \mathrm{CH}_{3} \mathrm{OCH}_{2} \mathrm{OCH}_{3}+\mathrm{OH} \rightleftharpoons \mathrm{CH}_{3} \mathrm{OCH}_{2} \mathrm{OCH}_{2}+\mathrm{H}_{2} \mathrm{O} \\
& \mathrm{CH}_{3} \mathrm{OCH}_{2} \mathrm{OCH}_{3}+\mathrm{OH} \rightleftharpoons \mathrm{CH}_{3} \mathrm{OCHOCH}_{3}+\mathrm{H}_{2} \mathrm{O}
\end{aligned}
$$

Both radicals react with molecular oxygen to form methyl formate $\left(\mathrm{CH}_{3} \mathrm{OCHO}\right)$ and formaldehyde as main products: 
$\mathrm{CH}_{3} \mathrm{OCH}_{2} \mathrm{OCH}_{2}+\mathrm{O}_{2} \rightleftharpoons \mathrm{CH}_{2} \mathrm{O}+\mathrm{CH}_{3} \mathrm{OCHO}+\mathrm{OH}$

$\mathrm{CH}_{3} \mathrm{OCHOCH}_{3}+\mathrm{O}_{2} \rightleftharpoons \mathrm{CH}_{2} \mathrm{O}+\mathrm{CH}_{3} \mathrm{OCHO}+\mathrm{OH}$

Formaldehyde continues the $\mathrm{CH}_{2} \mathrm{O} \rightarrow \mathrm{HCO} \rightarrow \mathrm{CO} \rightarrow \mathrm{CO}_{2}$ reaction sequence with $\mathrm{CO}_{2}$ as final product. As shown in Figure 3, MF seems to be an important intermediate in the total oxidation of DMM. In previous MF oxidation works, at atmospheric pressure [23] and higher pressures [16], the MF oxidation was seen to be initiated by its decomposition reaction to methanol (reaction 21). In this work, as an intermediate, MF is directly consumed by hydrogen abstraction reactions in order to produce $\mathrm{CH}_{2} \mathrm{OCHO}$ and $\mathrm{CH}_{3} \mathrm{OCO}$ radicals (reactions 22 and 23), with a relative importance, for example at 20 bar and oxidizing conditions $(\lambda=20)$, of $62 \%$ for reaction 22 and $20 \%$ for reaction 23 .

$$
\begin{aligned}
& \mathrm{CH}_{3} \mathrm{OCHO}(+\mathrm{M}) \rightleftharpoons \mathrm{CH}_{3} \mathrm{OH}+\mathrm{CO}(+\mathrm{M}) \\
& \mathrm{CH}_{3} \mathrm{OCHO}+\mathrm{OH} \rightleftharpoons \mathrm{CH}_{2} \mathrm{OCHO}+\mathrm{H}_{2} \mathrm{O} \\
& \mathrm{CH}_{3} \mathrm{OCHO}+\mathrm{OH} \rightleftharpoons \mathrm{CH}_{3} \mathrm{OCO}+\mathrm{H}_{2} \mathrm{O}
\end{aligned}
$$

Both radicals decompose thermically, $\mathrm{CH}_{2} \mathrm{OCHO}$ to give formaldehyde and formyl radical and $\mathrm{CH}_{3} \mathrm{OCO}$ to form methyl radical and $\mathrm{CO}_{2}$, through reactions 24 and 25, respectively:

$\mathrm{CH}_{2} \mathrm{OCHO} \rightleftharpoons \mathrm{CH}_{2} \mathrm{O}+\mathrm{HCO}$

$\mathrm{CH}_{3} \mathrm{OCO} \rightleftharpoons \mathrm{CH}_{3}+\mathrm{CO}_{2}$

As reported in an earlier work by our group for methyl formate oxidation [16], under highpressure conditions, high concentration of methyl and hydroperoxy radicals accumulate and thus, the interaction of those radicals can generate methoxy radicals through reaction 26 , which further decomposes to formaldehyde (reaction 27).

$$
\mathrm{CH}_{3}+\mathrm{HO}_{2} \rightleftharpoons \mathrm{CH}_{3} \mathrm{O}+\mathrm{OH}
$$




$$
\mathrm{CH}_{3} \mathrm{O}(+\mathrm{M}) \rightleftharpoons \mathrm{H}+\mathrm{CH}_{2} \mathrm{O}(+\mathrm{M})
$$

Therefore, formaldehyde is detected instead of methanol (highly formed in both MF oxidation [23] and DMM oxidation [15] at atmospheric pressure) when working under high pressure.

The formaldehyde obtained by this way continues the above mentioned $\mathrm{CH}_{2} \mathrm{O} \rightarrow \mathrm{HCO} \rightarrow \mathrm{CO} \rightarrow \mathrm{CO}_{2}$ reaction sequence. A fraction of this formaldehyde reacts with methyl radicals generating methane (reaction 28), which is detected as final product.

$\mathrm{CH}_{2} \mathrm{O}+\mathrm{CH}_{3} \rightleftharpoons \mathrm{HCO}+\mathrm{CH}_{4}$

Figure 4 shows the influence of pressure on the DMM, $\mathrm{CO}_{2}, \mathrm{CO}, \mathrm{CH}_{2} \mathrm{O}$ and $\mathrm{MF}$ concentration profiles as a function of temperature and for very oxidizing conditions, $\lambda=20$. As previously seen, working under high pressure conditions no appreciable influence of pressure on the conversion regime of DMM and products formation is found. Thus, similar results have been obtained for 20, 40 and 60 bar, and the slight differences that can be observed include a higher amount of methyl formate for 20 bar, while for the other two values of pressure, more $\mathrm{CO}_{2}$ is produced. For the pressures of 40 and $60 \mathrm{bar}$, in the $598-673 \mathrm{~K}$ temperature range, a constant concentration zone in the DMM profile and in the main products, $\mathrm{CO}_{2}, \mathrm{CO}, \mathrm{CH}_{3} \mathrm{OCHO}$ and $\mathrm{CH}_{2} \mathrm{O}$, can be observed. This zone appears to be associated to the oxygenated $\mathrm{CH}_{3} \mathrm{OCH}_{2} \mathrm{O}_{2}$ species. In the mechanism taken as starting point and used in the previous atmosphere work on DMM conversion [15], the formation reactions of this species were not included, and thus the predictions of the mechanism were significantly worse. Therefore, the formation reactions of this species from the interaction of $\mathrm{CH}_{3} \mathrm{OCH}_{2} \mathrm{OCH}_{2}$ and $\mathrm{O}_{2} / \mathrm{HO}_{2}$ (active species under oxidizing and high pressure conditions), reactions 19 and 20, were added to the mechanism:

$$
\mathrm{CH}_{3} \mathrm{OCH}_{2} \mathrm{OCH}_{2}+\mathrm{O}_{2} \rightleftharpoons \mathrm{CH}_{3} \mathrm{OCH}_{2} \mathrm{O}_{2}+\mathrm{CH}_{2} \mathrm{O}
$$


$\mathrm{CH}_{3} \mathrm{OCH}_{2} \mathrm{OCH}_{2}+\mathrm{HO}_{2} \rightleftharpoons \mathrm{CH}_{3} \mathrm{OCH}_{2} \mathrm{O}_{2}+\mathrm{CH}_{2} \mathrm{OH}$

With these two reactions, the current mechanism has been able to represent the plateau observed in DMM, $\mathrm{CO}_{2}$ and $\mathrm{CO}$ concentration, in the $598-673 \mathrm{~K}$ temperature range. The kinetic parameters of these reactions have been estimated due to the lack of literature determinations above mentioned, as has been described in the Modeling section. Reaction pathway analysis allows us to identify how the species are formed and proceed through the following reaction sequence: $\mathrm{CH}_{3} \mathrm{OCH}_{2} \mathrm{O}_{2} \rightarrow \mathrm{CH}_{2} \mathrm{OCH}_{2} \mathrm{O}_{2} \mathrm{H} \rightarrow \mathrm{O}_{2} \mathrm{CH}_{2} \mathrm{OCH}_{2} \mathrm{O}_{2} \mathrm{H} \rightarrow$ $\mathrm{HO}_{2} \mathrm{CH}_{2} \mathrm{OCHO} \rightarrow \mathrm{OCH}_{2} \mathrm{OCHO}$. The last one decomposes to give $\mathrm{CH}_{2} \mathrm{O}$ and $\mathrm{HCOO}$ through reaction 29:

$\mathrm{OCH}_{2} \mathrm{OCHO} \rightleftharpoons \mathrm{CH}_{2} \mathrm{O}+\mathrm{HCOO}$

Formaldehyde continues the $\mathrm{CH}_{2} \mathrm{O} \rightarrow \mathrm{HCO} \rightarrow \mathrm{CO} \rightarrow \mathrm{CO}_{2}$ well-known reaction sequence, whereas the hydrocarboxyl radical decomposes generating $\mathrm{CO}_{2}$ as final product:

$\mathrm{HCOO} \rightleftharpoons \mathrm{H}+\mathrm{CO}_{2}$

A first-order sensitivity analysis for $\mathrm{CO}$ has been performed for all the sets in Table 1 . The results obtained, shown in Table 3, indicate that the conversion of DMM is highly sensitive to the DMM reactions with $\mathrm{OH}$ radicals (reactions 9 and 10), which have been previously discussed. Reactions involving $\mathrm{MF}\left(\mathrm{CH}_{3} \mathrm{OCHO}\right)$ and its radicals also present a high sensitivity, as an important intermediate in the DMM oxidation under the conditions studied in the present work.

Figure 5 shows the experimental results obtained for stoichiometric conditions by our research group for the DMM oxidation at atmospheric pressure [15] and the high-pressure results, experimental and modeling, discussed in the present work. Although it can be observed a huge shift to lower temperatures when moving from atmospheric pressure to 
higher ones, the results can not be directly compared because both gas residence times are significantly different The gas residence time for the high pressure installation $\left(\mathrm{t}_{\mathrm{r}}(\mathrm{s})=261 * \mathrm{P}(\mathrm{bar}) / \mathrm{T}(\mathrm{K})\right)$ is longer than at atmospheric pressure $\left(\mathrm{t}_{\mathrm{r}}(\mathrm{s})=195 / \mathrm{T}(\mathrm{K})\right)$ by a factor of 27-80 and, therefore, it is not possible to distinguish between the effect of pressure or residence time. To overcome this problem, model calculations have been carried out, modifying either the residence time or the pressure input value.

To do this, the kinetic mechanism used to simulate the high pressure experiments of this work has also been used to simulate the results obtained in the DMM oxidation at atmospheric pressure [15].

Figure 6 shows, as an example, a comparison (only for $\mathrm{DMM}, \mathrm{CO}$ and $\mathrm{CO}_{2}$ concentrations) between the modeling results obtained with the initial mechanism [15] (dashed lines) or with the mechanism modified in the present work (solid lines) and the experimental results (symbols) attained at atmospheric pressure in the 573-1373 K temperature range, for an initial concentration of $700 \mathrm{ppm}$ of DMM and stoichiometric conditions [15]. $\mathrm{N}_{2}$ was used to achieve a total flow rate of $1000 \mathrm{~mL}(\mathrm{STP}) / \mathrm{min}$, resulting in a gas residence time dependent of the reaction temperature of $\mathrm{t}_{\mathrm{r}}(\mathrm{s})=195 / \mathrm{T}(\mathrm{K})$ [15]. As can be seen in Figure 6, the modified mechanism generates almost the same results of the mechanism of reference [15] and thus is able to predict the main trends of the DMM consumption profile and $\mathrm{CO}$ and $\mathrm{CO}_{2}$ formation.

With the validated kinetic mechanism of the present work, that describes well both low and high pressure experimental results, we have made different simulations to try to distinguish between the effect of residence time or pressure.

Figure 7 includes calculations for $\lambda=1$ and 20 bar, with a residence time of $t_{r}(s)=5220 / T(K)$ (solid lines) and for the same conditions ( $\lambda=1$ and 20 bar) but for a lower residence time of $\mathrm{t}_{\mathrm{r}}(\mathrm{s})=261 / \mathrm{T}(\mathrm{K})$ (short dashed lines), which would be the same as the residence time 
corresponding to 1 bar. As a reference, in Figure 7, also the experimental data of set 4 in Table 1 are included $(\lambda=1,20$ bar) and denoted by symbols. As can be seen, when only residence time is changed, increasing residence time shifts significantly the conversion of DMM towards lower temperatures.

Additionally, Figure 7 also includes calculations made with 1 bar of pressure and the residence time of the 20 bar experiments, i.e. $\mathrm{t}_{\mathrm{r}}(\mathrm{s})=5220 / \mathrm{T}(\mathrm{K})$ (long-dashed lines). Increasing pressure from 1 bar (long-dashed lines) to 20 bar (solid lines) but keeping a given residence time of $\mathrm{t}_{\mathrm{r}}(\mathrm{s})=5220 / \mathrm{T}(\mathrm{K})$ results in a similar shift of the DMM concentration profile as that reported for the change in time residence.

Thus, both the pressure and the residence time have an appreciable impact and are responsible for a significant shift in the oxidation regime of DMM.

\section{Conclusions}

The DMM conversion has been investigated in a quartz flow reactor in the $373-1073 \mathrm{~K}$ temperature range, for different air excess ratios $(\lambda=0.7,1$ and 20$)$ and pressures (20-60 bar). The experimental results have been interpreted in terms of a detailed kinetic mechanism, compiled in a previous work about the DMM oxidation at atmospheric pressure by our research group [15], and modified in the present work to account also for the high pressure conditions studied. The modeling results obtained with the modified mechanism are similar to those attained without any modification; that is, the new mechanism is able to predict the main trends observed for the DMM oxidation at atmospheric pressure.

Experimental results and model calculations are, in general, in good agreement, and the main trends are well predicted for the theoretical model. Slight differences are noticed when 
working under stoichiometric or somewhat fuel-rich conditions, although the DMM conversion is a bit different for oxidizing conditions. Working at 20, 40 or 60 bar does not have a big effect on neither the oxidation of DMM nor the formation of the main products.

Independently of the conditions (stoichiometric, oxidizing or reducing), the main consumption of DMM occurs through $\mathrm{H}$ abstraction reactions by the hydroxyl radical $(\mathrm{OH})$. Under oxidizing conditions, the conversion of DMM is fast until approximately the 598 to $673 \mathrm{~K}$ temperature zone, where the concentration of DMM presents a plateau and remains constant. This zone appears to be associated to the formation of the intermediate $\mathrm{CH}_{3} \mathrm{OCH}_{2} \mathrm{O}_{2}$ oxygenated species. The formation reactions of this species from the interaction of $\mathrm{CH}_{3} \mathrm{OCH}_{2} \mathrm{OCH}_{2}$ and $\mathrm{O}_{2} / \mathrm{HO}_{2}$, active species under oxidizing and high pressure conditions, were not initially considered in the DMM reaction subset taken from the literature [14]. Therefore, these reactions were added to the mechanism.

The analysis of the main reaction pathways involved in the DMM conversion, occurring under the conditions studied in the present work, has shown that methyl formate plays an important role in this process.

The experimental results obtained under high-pressure conditions in the present work are shifted towards lower temperatures compared to those obtained at atmospheric pressure by Marrodán et al. [15], for different residence times. Model calculations have been performed to evaluate independently the effect of pressure and gas residence time and results indicate that both variables have remarkable influence on the DMM oxidation process. 


\section{Acknowledgements}

The authors express their gratitude to the Aragón Government (GPT group) and to MINECO and FEDER (Project CTQ2012-34423), for financial support.

\section{Supporting Information}

The full mechanism listing including the thermodynamic data additional to THERMDAT [41]. This material is available free of charge via the Internet at http://pubs.acs.org.

\section{References}

[1] Zhu, R.; Wang, X.; Miao, H.; Yang, X.; Huang, Z. Fuel 2011, 90, 1731-1737.

[2] Vertin, K.D; Ohi, J.M; Naegeli, D.W.; Childress, K.H.; Hagen, G.P.; McCarthy, C.I.; Cheng, A.S.; Dibble, R.W. SAE technical paper 1999-01-1508, 1999.

[3] Yanfeng, G.; Shenghua, L.; Hejun, G.; Tiegang, H.; Longbao, Z. Appl. Therm. Eng. 2007, 27, 202-207.

[4] Zhu, R.; Miao, H.; Wang, X.; Huang, Z. Proc. Combust. Inst. 2013, 34, 3013-3020.

[5] Ren, Y.; Huang, Z.; Miao, H.; Di, Y.; Jiang, D.; Zeng, K.; Liu, B.; Wang, X. Fuel 2008, 87, 2691-2697.

[6] Ying, W.; Longbao, Z.; Hewu, W. Atmos. Environ. 2006, 40, 2313-2320

[7] Arcoumanis, C.; Bae, C.; Crookes, R.; Kinoshita, E. Fuel 2008, 87, 1014-1030.

[8] Ren, Y.; Huang, Z.; Jiang, D.; Liu, L.; Zeng, K.; Liu, B.; Wang, X. Appl. Therm. Eng. 2006, 26, 327-337.

[9] Huang, Z.H.; Ren, Y.; Jiang, D.M.; Liu, L.X.; Zeng, K.; Liu, B.; Wang, X.B. Energy Convers. Manage. 2006, 47, 1402-1415.

[10] Sathiyagnanam, A.P.; Saravanan, C.G. Fuel 2008, 87, 2281-2285. 
[11] Chen, G.; Yu, W.; Fu, J.; Mo, J.; Huang, Z.; Yang, J.; Wang, Z.; Jin, H.; Qi, F. Combust. Flame 2012, 159, 2324-2335.

[12] Zhang, C.; Li, P.; Li, Y.; He, J.; Li, X. Energy Fuels 2014, 28, 4603-4610.

[13] Daly, C.A.; Simmie, J.M.; Dagaut, P.; Cathonnet, M. Combust. Flame 2001, 125, 1106-1117.

[14] Dias, V.; Lories, X.; Vandooren, J. Combust. Sci. Technol. 2010, 182, 350-364.

[15] Marrodán, L.; Monge, F.; Millera, A.; Bilbao, R.; Alzueta, M.U. (Accepted for presentation in the Ninth Mediterranean Combustion Symposium, Rhodes, Greece, June 2015)

[16] Marrodán, L.; Millera, A.; Bilbao, R.; Alzueta, M.U. Energy Fuels 2014, 28, 61076115.

[17] Glarborg, P.; Alzueta, M.U.; Dam-Johansen, K.; Miller, J.A. Combust. Flame 1998, $115,1-27$

[18] Glarborg, P.; Alzueta, M.U.; Kjærgaard, K; Dam-Johansen, K. Combust. Flame 2003, $132,629-638$.

[19] Skjøth-Rasmussen, M.S.; Glarborg, P.; Østberg, M.; Johannessen, J.T.; Livbjerg, H.; Jensen, A.D.; Christensen, T.S. Combust. Flame 2004, 136, 91-128.

[20] Alzueta, M.U.; Muro, J.; Bilbao, R.; Glarborg, P. Isr. J. Chem. 1999, 39, 73-86.

[21] Alzueta, M.U.; Hernández, J.M. Energy Fuels 2002, 16, 166-171.

[22] Alzueta, M.U.; Borruey, M.; Callejas, A.; Millera, A.; Bilbao, R. Combust. Flame 2008, 152, 377-386

[23] Alzueta, M.U.; Aranda, V.; Monge, F.; Millera, A.; Bilbao, R. Combust. Flame 2013, $160,853-860$.

[24] Dagaut, P.; Boettner, J.C.; Cathonnet, M. Proc. Combust. Inst. 1996, 26, 627-632. 
[25] Mallard, W.G.; Westley, F.; Herron, J.T.; Hampson, R.F. NIST Chemical Kinetics Database 6.01 1994.

[26] Foucaut, J.F.; Martin, R. J. Chim. Phys. 1978, 75, 132-144.

[27] Dean, A.M. J. Phys. Chem. 1985, 89, 4600-4608.

[28] Dagaut, P.; Daly, C.; Simmie, J.M.; Cathonnet, M. Proc. Combust. Inst. 1998, 27, 361369.

[29] Faubel, C.; Hoyermann, K.; Strofer, E.; Wagner, H. Ber Bunsenges Phys. Chem. 1979, $83,532-538$.

[30] Herron, J.T. J. Phys. Chem. Ref. Data 1988, 17, 967-1026.

[31] Arif, M.; Dellinger, B.; Taylor, P.H. J. Phys. Chem. A 1997, 101, 2436-2441.

[32] DeMore, W.B.; Bayes, K.D. J. Phys. Chem. A 1999, 103, 2649-2654.

[33] Cook, R.D.; Davidson, D.F.; Hanson, R.K. J. Phys. Chem. A 2009, 113, 9974-9980.

[34] Curran, H.J.; Pitz, W.J., Westbrook, C.K.; Dagaut, P.; Boettner, J.C.; Cathonnet, M. Int. J. Chem. Kinet. 1998, 30, 229-241.

[35] Sehested, J.; Sehested, K.; Platz, J.; Egsgaard, H.; Nielsen, O.J. Int. J. Chem. Kinet. 1997, 29, 627-637.

[36] Sehested, J.; Mogelberg, T.; Wallington, T.J.; Kaiser, E.W.; Nielsen, O.J. J. Phys. Chem. 1996, 100, 17218-17225.

[37] Hoyerman, K.; Nacke, F. Proc. Combust. Inst. 1996, 26, 505-512.

[38] Lutz, A.E.; Kee, R.J.; Miller, J.A. SENKIN: A FORTRAN Program for Predicting Homogeneous Gas Phase Chemical Kinetics with Sensitivity Analysis; Sandia National Laboratories: Livermore, CA, 1988; Report SAND87-8248.

[39] Kee, R.J.; Rupley, F.M.; Miller, J.A. CHEMKIN-II: A FORTRAN Chemical Kinetics Package for the Analysis of Gas-Phase Chemical Kinetics; Sandia National Laboratories: Albuquerque, NM, 1991; Report SAND87-8215. 
[40] CHEMKIN-PRO, Release 15131, Reaction Design, San Diego, 2013.

[41] Burcat, A.; Ruscic, B. Third Millennium Ideal Gas and Condensed Phase Thermochemical Database for Combustion with Updates from Active Thermochemical Tables, Report TAE960, Technion Israel Inst. of Technology, $16^{\text {th }}$ September 2005. 


\section{Table captions}

Table 1. Matrix of experimental conditions. The experiments are conducted at constant flow rate of $1000 \mathrm{~mL}(\mathrm{STP}) / \mathrm{min}$, in the temperature interval of 373-1073 K. The balance is closed with $\mathrm{N}_{2}$. The residence time depends on the reaction temperature and pressure: $\mathrm{t}_{\mathrm{r}}(\mathrm{s})=261 * \mathrm{P}($ bar $) / \mathrm{T}(\mathrm{K})$.

Table 2. Reactions modified or included in the final mechanism in relation to the mechanism used in reference [15] and corresponding kinetic parameters.

Table 3. Linear sensitivity coefficients for CO for sets 1-9 in Table 1 . The sensitivity coefficients are given as $A_{i} \delta Y_{j} / Y_{j} \delta A_{i}$, where $A_{i}$ is the pre-exponential constant for reaction $i$ and $Y_{j}$ is the mass fraction of $j_{t h}$ species. Therefore, the sensitivity coefficients listed can be interpreted as the relative change in predicted concentration for the species $j$ caused by increasing the rate constant for reaction $i$ by a factor of 2 . 


\section{Tables}

\section{Table 1.}

Matrix of experimental conditions. The experiments are conducted at constant flow rate of $1000 \mathrm{~mL}(\mathrm{STP}) / \mathrm{min}$, in the temperature interval of $373-1073 \mathrm{~K}$. The balance is closed with $\mathrm{N}_{2}$. The residence time depends on the reaction temperature and pressure: $\mathrm{t}_{\mathrm{r}}(\mathrm{s})=261 * \mathrm{P}(\mathrm{bar}) / \mathrm{T}(\mathrm{K})$.

\begin{tabular}{ccccc}
\hline Exp. & DMM (ppm) & $\mathbf{O}_{\mathbf{2}}(\mathbf{p p m})$ & $\boldsymbol{\lambda}$ & $\mathbf{P}(\mathbf{b a r})$ \\
\hline Set 1 & 720 & 1960 & 0.7 & 20 \\
Set 2 & 770 & 1960 & 0.7 & 40 \\
Set 3 & 770 & 1960 & 0.7 & 60 \\
Set 4 & 757 & 2800 & 1 & 20 \\
Set 5 & 720 & 2800 & 1 & 40 \\
Set 6 & 720 & 2800 & 1 & 60 \\
Set 7 & 688 & 56000 & 20 & 20 \\
Set 8 & 778 & 56000 & 20 & 40 \\
Set 9 & 706 & 56000 & 20 & 60 \\
\hline
\end{tabular}


Table 2.

Reactions modified or included in the final mechanism in relation to the mechanism used in reference [15] and corresponding kinetic parameters.

\begin{tabular}{|c|c|c|c|c|c|}
\hline Number & Reaction & $\mathbf{A}$ & $\mathbf{n}$ & $\mathbf{E}_{\mathrm{a}}$ & Source \\
\hline 9 & $\mathrm{CH}_{3} \mathrm{OCH}_{2} \mathrm{OCH}_{3}+\mathrm{OH} \rightleftharpoons \mathrm{CH}_{3} \mathrm{OCH}_{2} \mathrm{OCH}_{2}+\mathrm{H}_{2} \mathrm{O}$ & $6.32 \times 10^{6}$ & 2.00 & -652 & $\begin{array}{c}{[22,32,34,} \\
\text { see text }]\end{array}$ \\
\hline 10 & $\mathrm{CH}_{3} \mathrm{OCH}_{2} \mathrm{OCH}_{3}+\mathrm{OH} \rightleftharpoons \mathrm{CH}_{3} \mathrm{OCHOCH}_{3}+\mathrm{H}_{2} \mathrm{O}$ & $6.32 \times 10^{6}$ & 2.00 & -652 & $\begin{array}{c}{[22,32,34,} \\
\text { see text }]\end{array}$ \\
\hline 11 & $\mathrm{CH}_{3} \mathrm{OCH}_{2} \mathrm{OCH}_{3}+\mathrm{HO}_{2} \rightleftharpoons \mathrm{CH}_{3} \mathrm{OCH}_{2} \mathrm{OCH}_{2}+\mathrm{H}_{2} \mathrm{O}_{2}$ & $1.00 \times 10^{13}$ & 0.00 & 17686 & [35] \\
\hline 12 & $\mathrm{CH}_{3} \mathrm{OCH}_{2} \mathrm{OCH}_{3}+\mathrm{HO}_{2} \rightleftharpoons \mathrm{CH}_{3} \mathrm{OCHOCH}_{3}+\mathrm{H}_{2} \mathrm{O}_{2}$ & $2.00 \times 10^{12}$ & 0.00 & 15296 & [13] \\
\hline 15 & $\mathrm{CH}_{3} \mathrm{OCH}_{2} \mathrm{OCH}_{2}+\mathrm{O}_{2} \rightleftharpoons \mathrm{CH}_{2} \mathrm{O}+\mathrm{CH}_{3} \mathrm{OCHO}+\mathrm{OH}$ & $2.50 \times 10^{11}$ & 0.00 & -1700 & [22] \\
\hline 16 & $\mathrm{CH}_{3} \mathrm{OCHOCH}{ }_{3}+\mathrm{O}_{2} \rightleftharpoons \mathrm{CH}_{2} \mathrm{O}+\mathrm{CH}_{3} \mathrm{OCHO}+\mathrm{OH}$ & $2.50 \times 10^{11}$ & 0.00 & -1700 & [22] \\
\hline 17 & $\mathrm{CH}_{3} \mathrm{OCH}_{2} \mathrm{OCH}_{2}+\mathrm{HO}_{2} \rightleftharpoons \mathrm{CH}_{2} \mathrm{O}+\mathrm{CH}_{3} \mathrm{OCH}_{2} \mathrm{O}+\mathrm{OH}$ & $3.00 \times 10^{11}$ & 0.00 & 0 & [13] \\
\hline 18 & $\mathrm{CH}_{3} \mathrm{OCHOCH}_{3}+\mathrm{HO}_{2} \rightleftharpoons \mathrm{CH}_{3} \mathrm{OCHO}+\mathrm{CH}_{3} \mathrm{O}+\mathrm{OH}$ & $1.00 \times 10^{12}$ & 0.00 & 0 & [13] \\
\hline 19 & $\mathrm{CH}_{3} \mathrm{OCH}_{2} \mathrm{OCH}_{2}+\mathrm{O}_{2} \rightleftharpoons \mathrm{CH}_{3} \mathrm{OCH}_{2} \mathrm{O}_{2}+\mathrm{CH}_{2} \mathrm{O}$ & $6.40 \times 10^{12}$ & 0.00 & 91 & see text \\
\hline 20 & $\mathrm{CH}_{3} \mathrm{OCH}_{2} \mathrm{OCH}_{2}+\mathrm{HO}_{2} \rightleftharpoons \mathrm{CH}_{3} \mathrm{OCH}_{2} \mathrm{O}_{2}+\mathrm{CH}_{2} \mathrm{OH}$ & $1.00 \times 10^{12}$ & 0.00 & 0 & see text \\
\hline
\end{tabular}

$\mathrm{A}$ in units of $\mathrm{cm}^{3}$, mol, $\mathrm{s} ; \mathrm{E}_{\mathrm{a}}$ in $\mathrm{cal} / \mathrm{mol}$ 
Table 3.

Linear sensitivity coefficients for $\mathrm{CO}$ for sets 1-9 in Table 1 . The sensitivity coefficients are given as $A_{i} \delta Y_{j} / Y_{j} \delta A_{i}$, where $A_{i}$ is the pre-exponential constant for reaction $i$ and $Y_{j}$ is the mass fraction of $j_{t h}$ species. Therefore, the sensitivity coefficients listed can be interpreted as the relative change in predicted concentration for the species $j$ caused by increasing the rate constant for reaction $i$ by a factor of 2 .

\begin{tabular}{|c|c|c|c|c|c|c|c|c|c|}
\hline Reaction & $\begin{array}{c}\text { set } 1 \\
(623 \mathrm{~K})\end{array}$ & $\begin{array}{c}\text { set } 2 \\
(623 \mathrm{~K})\end{array}$ & $\begin{array}{c}\text { set } 3 \\
(573 \mathrm{~K})\end{array}$ & $\begin{array}{c}\text { set } 4 \\
(673 \mathrm{~K})\end{array}$ & $\begin{array}{c}\text { set } 5 \\
(623 \mathrm{~K})\end{array}$ & $\begin{array}{c}\text { set } 6 \\
(523 \mathrm{~K})\end{array}$ & $\begin{array}{c}\text { set } 7 \\
(548 \text { K) }\end{array}$ & $\begin{array}{c}\text { set } 8 \\
(548 \mathrm{~K})\end{array}$ & $\begin{array}{c}\text { set } 9 \\
(548 \mathrm{~K})\end{array}$ \\
\hline (9) $\mathrm{CH}_{3} \mathrm{OCH}_{2} \mathrm{OCH}_{3}+\mathrm{OH}=\mathrm{CH}_{3} \mathrm{OCH}_{2} \mathrm{OCH}_{2}+\mathrm{H}_{2} \mathrm{O}$ & 1.019 & 0.958 & 0.989 & 1.303 & 0.974 & 1.160 & 1.397 & 1.350 & 1.303 \\
\hline (10) $\mathrm{CH}_{3} \mathrm{OCH}_{2} \mathrm{OCH}_{3}+\mathrm{OH}=\mathrm{CH}_{3} \mathrm{OCHOCH}_{3}+\mathrm{H}_{2} \mathrm{O}$ & -0.219 & -0.230 & -0.352 & -0.479 & -0.251 & -0.392 & -0.487 & -0.485 & -0.479 \\
\hline (11) $\mathrm{CH}_{3} \mathrm{OCH}_{2} \mathrm{OCH}_{3}+\mathrm{HO}_{2}=\mathrm{CH}_{3} \mathrm{OCH}_{2} \mathrm{OCH}_{2}+\mathrm{H}_{2} \mathrm{O}_{2}$ & 0.112 & 0.126 & 0.025 & 0.025 & 0.097 & 0.046 & 0.022 & 0.025 & 0.025 \\
\hline (12) $\mathrm{CH}_{3} \mathrm{OCH}_{2} \mathrm{OCH}_{3}+\mathrm{HO}_{2}=\mathrm{CH}_{3} \mathrm{OCHOCH}_{3}+\mathrm{H}_{2} \mathrm{O}_{2}$ & 0.126 & 0.124 & 0.022 & 0.033 & 0.087 & 0.086 & 0.035 & 0.036 & 0.033 \\
\hline (14) $\mathrm{CH}_{3} \mathrm{OCH}_{2} \mathrm{OCH}_{3}+\mathrm{O}_{2}=\mathrm{CH}_{3} \mathrm{OCHOCH}_{3}+\mathrm{HO}_{2}$ & - & - & 0.001 & 0.001 & - & 0.017 & 0.007 & 0.003 & 0.001 \\
\hline (16) $\mathrm{CH}_{3} \mathrm{OCH}_{2} \mathrm{OCH}_{2}+\mathrm{O}_{2}=\mathrm{CH}_{2} \mathrm{O}+\mathrm{CH}_{3} \mathrm{OCHO}+\mathrm{OH}$ & -0.184 & -0.177 & -0.216 & -0.302 & -0.182 & -0.280 & -0.322 & -0.312 & -0.302 \\
\hline (19) $\mathrm{CH}_{3} \mathrm{OCH}_{2} \mathrm{OCH}_{2}+\mathrm{O}_{2}(+\mathrm{M})=\mathrm{CH}_{3} \mathrm{OCH}_{2} \mathrm{O}_{2}+\mathrm{CH}_{2} \mathrm{O}(+\mathrm{M})$ & 0.179 & 0.174 & 0.214 & 0.301 & 0.179 & 0.279 & 0.317 & 0.309 & 0.301 \\
\hline $\mathrm{CH}_{3} \mathrm{OCH}_{2}+\mathrm{O}_{2}=\mathrm{CH}_{2} \mathrm{O}+\mathrm{CH}_{2} \mathrm{O}+\mathrm{OH}$ & -0.021 & -0.017 & -0.008 & -0.001 & -0.017 & -0.002 & -0.001 & -0.001 & -0.001 \\
\hline $\mathrm{CH}_{2} \mathrm{OCH}_{2} \mathrm{O}_{2} \mathrm{H}=\mathrm{CH}_{2} \mathrm{O}+\mathrm{CH}_{2} \mathrm{O}+\mathrm{OH}$ & -1.479 & -1.223 & -0.705 & -0.024 & -1.164 & -0.167 & -0.075 & -0.037 & -0.024 \\
\hline $\mathrm{CH}_{3} \mathrm{OCH}_{2} \mathrm{O}_{2}=\mathrm{CH}_{2} \mathrm{OCH}_{2} \mathrm{O}_{2} \mathrm{H}$ & 0.001 & 0.001 & 0.001 & 0.006 & 0.001 & 0.016 & 0.017 & 0.009 & 0.006 \\
\hline $\mathrm{O}_{2} \mathrm{CH}_{2} \mathrm{OCH}_{2} \mathrm{O}_{2} \mathrm{H}=\mathrm{CH}_{2} \mathrm{OCH}_{2} \mathrm{O}_{2} \mathrm{H}+\mathrm{O}_{2}$ & 1.503 & 1.242 & 0.725 & 0.028 & 1.183 & 0.296 & 0.107 & 0.045 & 0.028 \\
\hline $\mathrm{HO}_{2} \mathrm{CH}_{2} \mathrm{OCHO}=\mathrm{OCH}_{2} \mathrm{OCHO}+\mathrm{OH}$ & -0.028 & -0.008 & 0.559 & 1.468 & -0.006 & 1.659 & 1.795 & 1.614 & 1.468 \\
\hline $\mathrm{CH}_{3} \mathrm{OCHO}+\mathrm{OH}=\mathrm{CH}_{2} \mathrm{OCHO}+\mathrm{H}_{2} \mathrm{O}$ & 0.071 & 0.059 & 0.023 & -0.031 & 0.061 & -0.054 & -0.057 & -0.044 & -0.031 \\
\hline $\mathrm{CH}_{3} \mathrm{OCHO}+\mathrm{OH}=\mathrm{CH}_{3} \mathrm{OCO}+\mathrm{H}_{2} \mathrm{O}$ & 0.002 & 0.004 & -0.011 & -0.021 & 0.004 & -0.017 & -0.023 & -0.022 & -0.021 \\
\hline $\mathrm{CH}_{2} \mathrm{OCHO}+\mathrm{HO}_{2}=\mathrm{HO}_{2} \mathrm{CH}_{2} \mathrm{OCHO}$ & 0.011 & 0.017 & 0.007 & -0.010 & 0.017 & -0.002 & -0.007 & -0.009 & -0.010 \\
\hline $\mathrm{H}+\mathrm{O}_{2}+\mathrm{N}_{2}=\mathrm{HO}_{2}+\mathrm{N}_{2}$ & -0.014 & -0.010 & -0.001 & 0.000 & -0.005 & 0.000 & 0.000 & 0.000 & 0.000 \\
\hline $\mathrm{OH}+\mathrm{HO}_{2}=\mathrm{H}_{2} \mathrm{O}+\mathrm{O}_{2}$ & -0.006 & -0.005 & -0.001 & -0.002 & -0.005 & -0.002 & -0.006 & -0.003 & -0.002 \\
\hline $\mathrm{HO}_{2}+\mathrm{HO}_{2}=\mathrm{H}_{2} \mathrm{O}_{2}+\mathrm{O}_{2}$ & -0.160 & -0.234 & -0.056 & -0.039 & -0.192 & -0.063 & -0.026 & -0.036 & -0.039 \\
\hline $\mathrm{H}_{2} \mathrm{O}_{2}+\mathrm{M}=\mathrm{OH}+\mathrm{OH}+\mathrm{M}$ & 0.091 & 0.310 & 0.008 & 0.001 & 0.291 & 0.000 & 0.000 & 0.001 & 0.001 \\
\hline $\mathrm{H}_{2} \mathrm{O}_{2}+\mathrm{OH}=\mathrm{H}_{2} \mathrm{O}+\mathrm{HO}_{2}$ & -0.012 & -0.030 & -0.027 & -0.025 & -0.037 & -0.002 & -0.008 & -0.017 & -0.025 \\
\hline $\mathrm{CH}_{2} \mathrm{O}+\mathrm{OH}=\mathrm{HCO}+\mathrm{H}_{2} \mathrm{O}$ & -0.851 & -0.749 & -0.608 & -0.732 & -0.735 & -0.692 & -0.811 & -0.771 & -0.732 \\
\hline $\mathrm{CH}_{2} \mathrm{O}+\mathrm{HO}_{2}=\mathrm{HCO}+\mathrm{H}_{2} \mathrm{O}_{2}$ & 0.094 & 0.231 & 0.063 & 0.037 & 0.209 & 0.013 & 0.013 & 0.027 & 0.037 \\
\hline $\mathrm{HCO}+\mathrm{M}=\mathrm{H}+\mathrm{CO}+\mathrm{M}$ & 0.014 & 0.009 & 0.003 & 0.000 & 0.004 & 0.001 & 0.000 & 0.000 & 0.000 \\
\hline $\mathrm{HCO}+\mathrm{O}_{2}=\mathrm{HO}_{2}+\mathrm{CO}$ & -0.016 & -0.012 & 0.095 & 0.001 & -0.007 & 0.255 & 0.006 & 0.003 & 0.001 \\
\hline
\end{tabular}




\section{Figure captions}

Fig. 1. Influence of pressure on the DMM, $\mathrm{CO}_{2}, \mathrm{CO}, \mathrm{CH}_{2} \mathrm{O}, \mathrm{CH}_{3} \mathrm{OCHO}$ and $\mathrm{CH}_{4}$ concentration profiles as a function of temperature for a given air excess ratio $(\lambda=0.7)$. Sets 1 3 in Table 1.

Fig. 2. Influence of pressure on the $\mathrm{DMM}, \mathrm{CO}_{2}, \mathrm{CO}, \mathrm{CH}_{2} \mathrm{O}, \mathrm{CH}_{3} \mathrm{OCHO}$ and $\mathrm{CH}_{4}$ concentration profiles as a function of temperature for a given air excess ratio $(\lambda=1)$. Sets 4-6 in Table 1.

Fig. 3. Reaction path diagram for DMM oxidation according to the current kinetic model in the 373-1073 K temperature range. Solid lines represent the main reaction pathways for all the conditions considered in the present work. Dashed lines refer to reaction paths that become more relevant under oxidizing conditions $(\lambda=20)$ and increasing pressure.

Fig. 4. Influence of pressure on the $\mathrm{DMM}, \mathrm{CO}_{2}, \mathrm{CO}, \mathrm{CH}_{2} \mathrm{O}$ and $\mathrm{CH}_{3} \mathrm{OCHO}$ concentration profiles as a function of temperature for a given air excess ratio $(\lambda=20)$. Sets $7-9$ in Table 1.

Fig. 5. Results for stoichiometric conditions, at 1 bar (experimental) from Marrodán et al. [15] and at high-pressure (experimental and modeling) from the present work [pw], sets 4-6 in Table 1.

Fig. 6. Comparison (for $\mathrm{DMM}, \mathrm{CO}$ and $\mathrm{CO}_{2}$ concentrations) between modeling calculations obtained with the initial mechanism [15] and the mechanism used in the present work for the experimental results obtained at atmospheric pressure and $\lambda=1$, for the conditions indicated in [15].

Fig. 7. Evaluation through model calculations of the effect of gas residence time (comparison between solid lines, $\mathrm{t}_{\mathrm{r}}(\mathrm{s})=5220 / \mathrm{T}(\mathrm{K})$, and short-dashed lines, $\left.\mathrm{t}_{\mathrm{r}}(\mathrm{s})=261 / \mathrm{T}(\mathrm{K})\right)$ and pressure (comparison between solid lines, $\mathrm{t}_{\mathrm{r}}(\mathrm{s})=5220 / \mathrm{T}(\mathrm{K})$ ), and long-dashed lines, $\mathrm{t}_{\mathrm{r}}(\mathrm{s})=5220 / \mathrm{T}(\mathrm{K})$ ) for a selected example under the conditions indicated in set 4 , Table 1. 


\section{Figures}

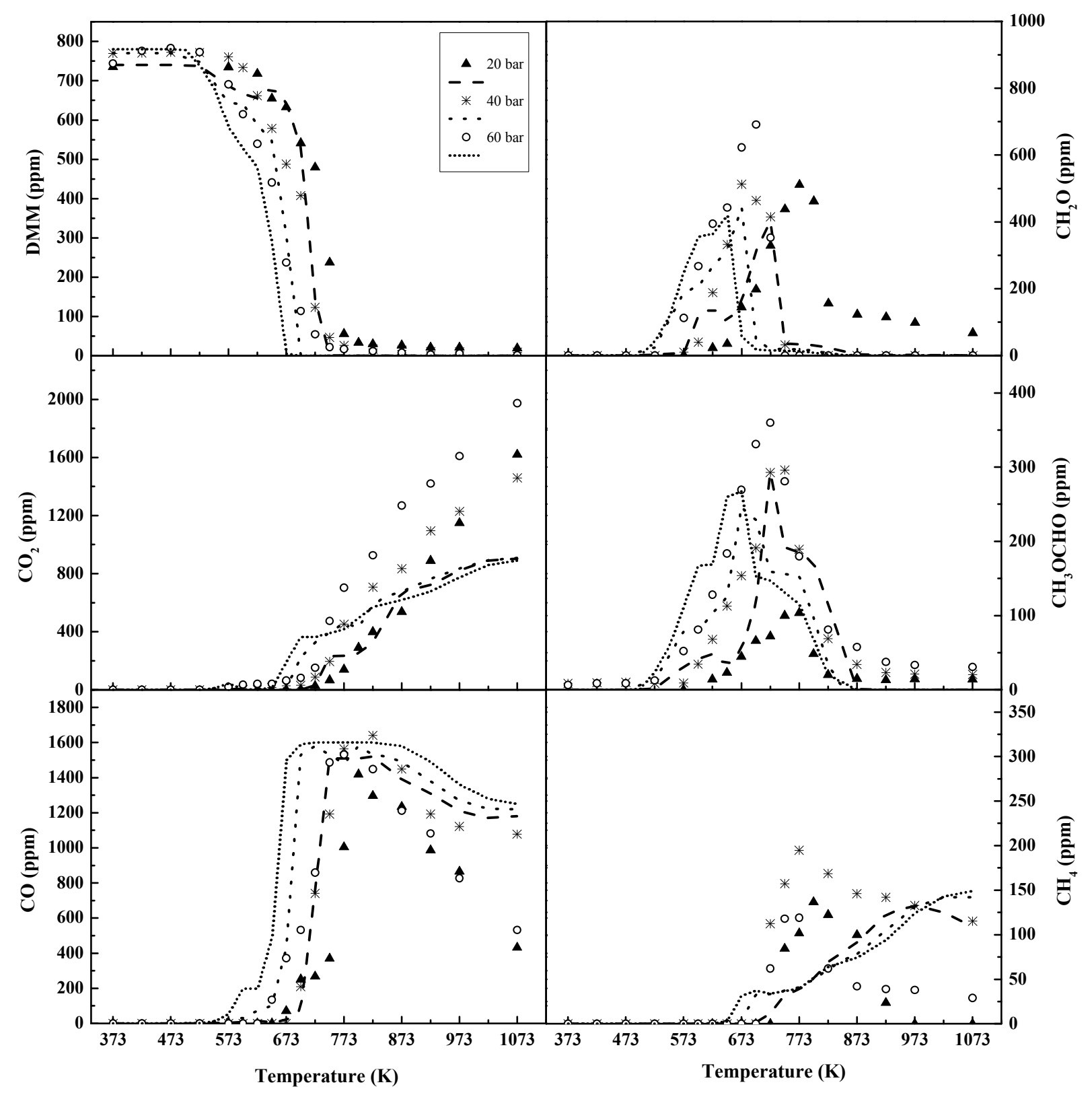

Fig. 1. Influence of pressure on the DMM, $\mathrm{CO}_{2}, \mathrm{CO}, \mathrm{CH}_{2} \mathrm{O}, \mathrm{CH}_{3} \mathrm{OCHO}$ and $\mathrm{CH}_{4}$ concentration profiles as a function of temperature for a given air excess ratio $(\lambda=0.7)$. Sets 1 3 in Table 1. 


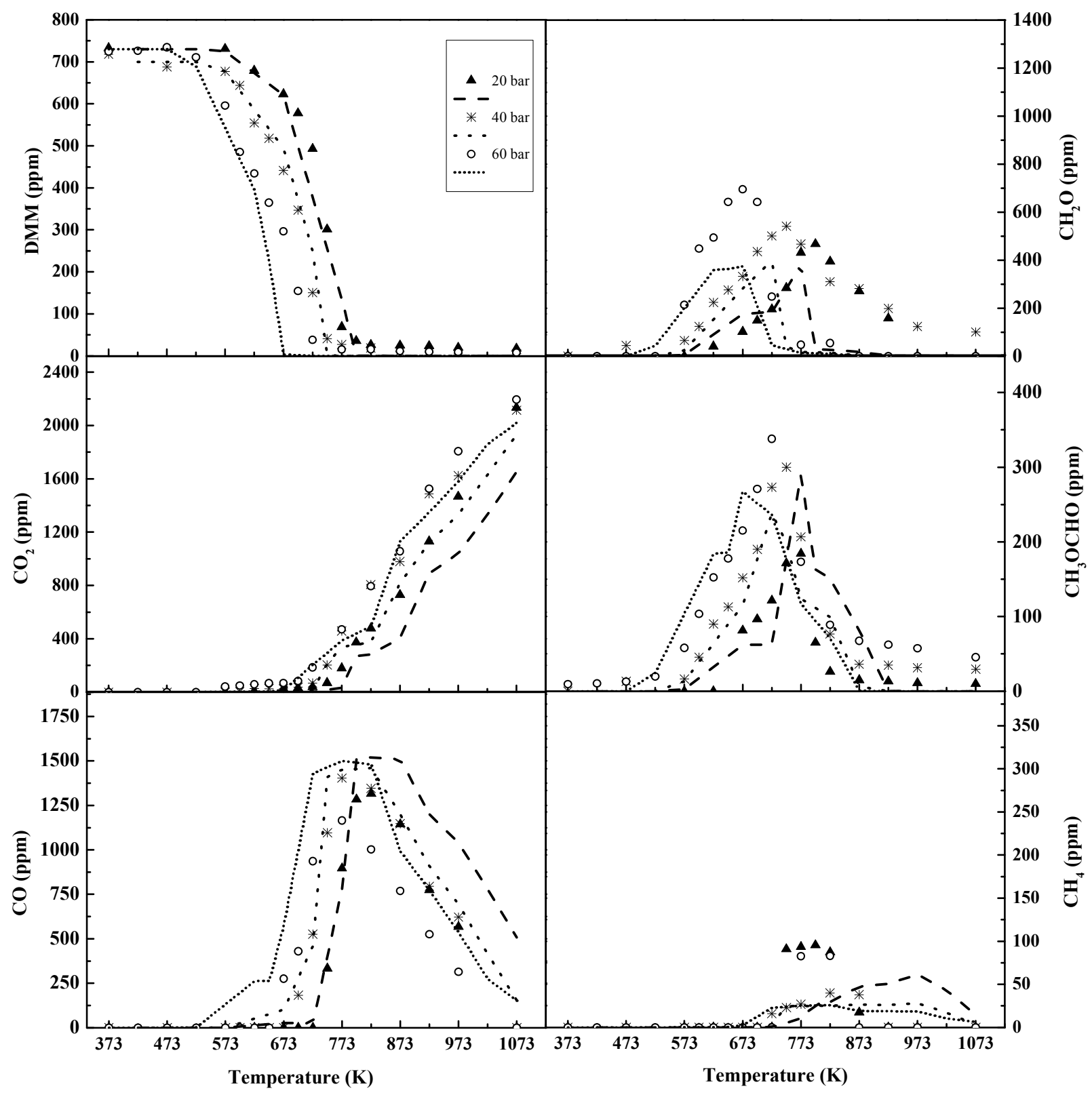

Fig. 2. Influence of pressure on the $\mathrm{DMM}, \mathrm{CO}_{2}, \mathrm{CO}, \mathrm{CH}_{2} \mathrm{O}, \mathrm{CH}_{3} \mathrm{OCHO}$ and $\mathrm{CH}_{4}$ concentration profiles as a function of temperature for a given air excess ratio $(\lambda=1)$. Sets $4-6$ in Table 1. 


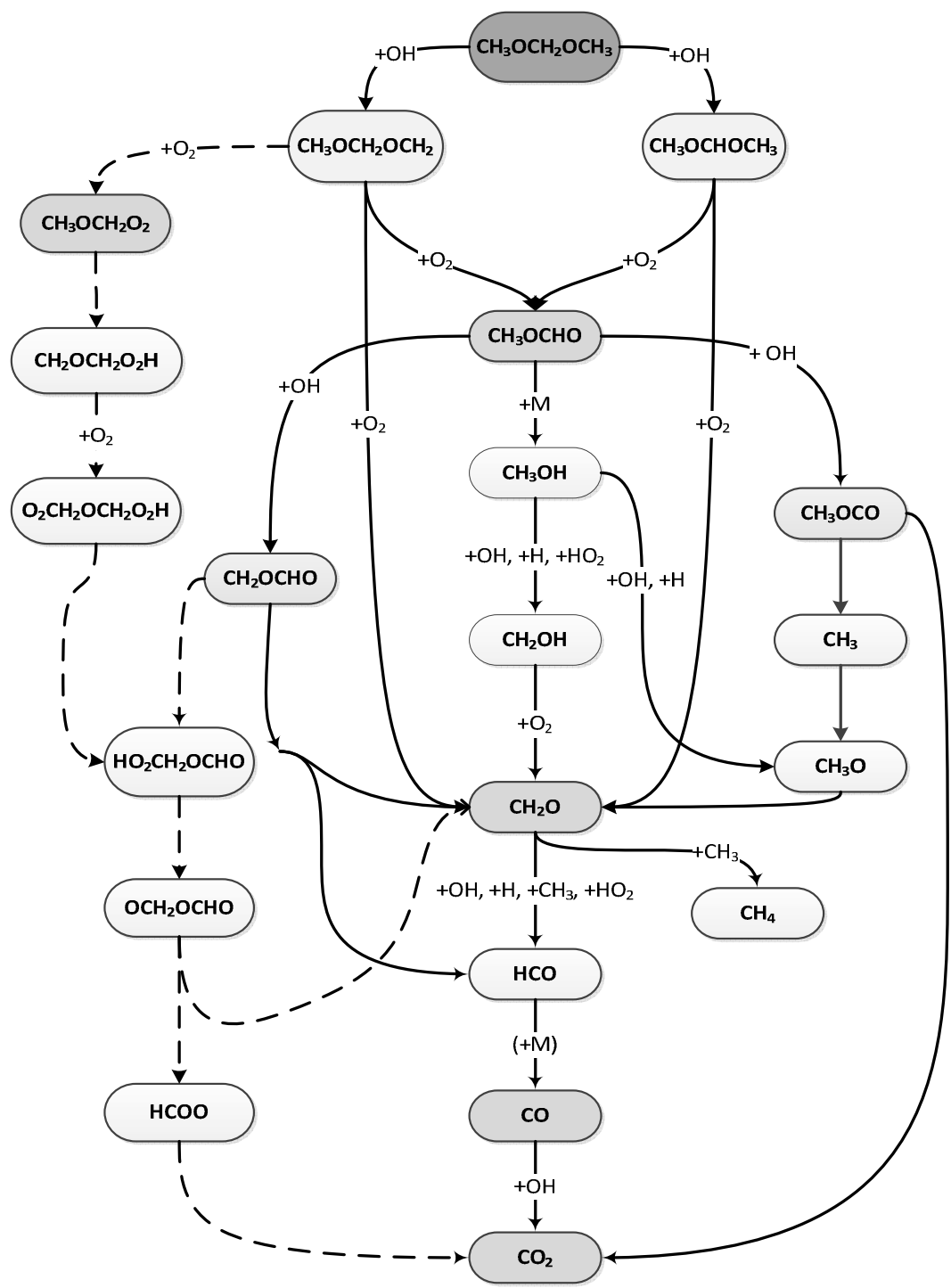

Fig. 3. Reaction path diagram for DMM oxidation according to the current kinetic model in the $373-1073 \mathrm{~K}$ temperature range. Solid lines represent the main reaction pathways for all the conditions considered in the present work. Dashed lines refer to reaction paths that become more relevant under oxidizing conditions $(\lambda=20)$ and increasing pressure. 


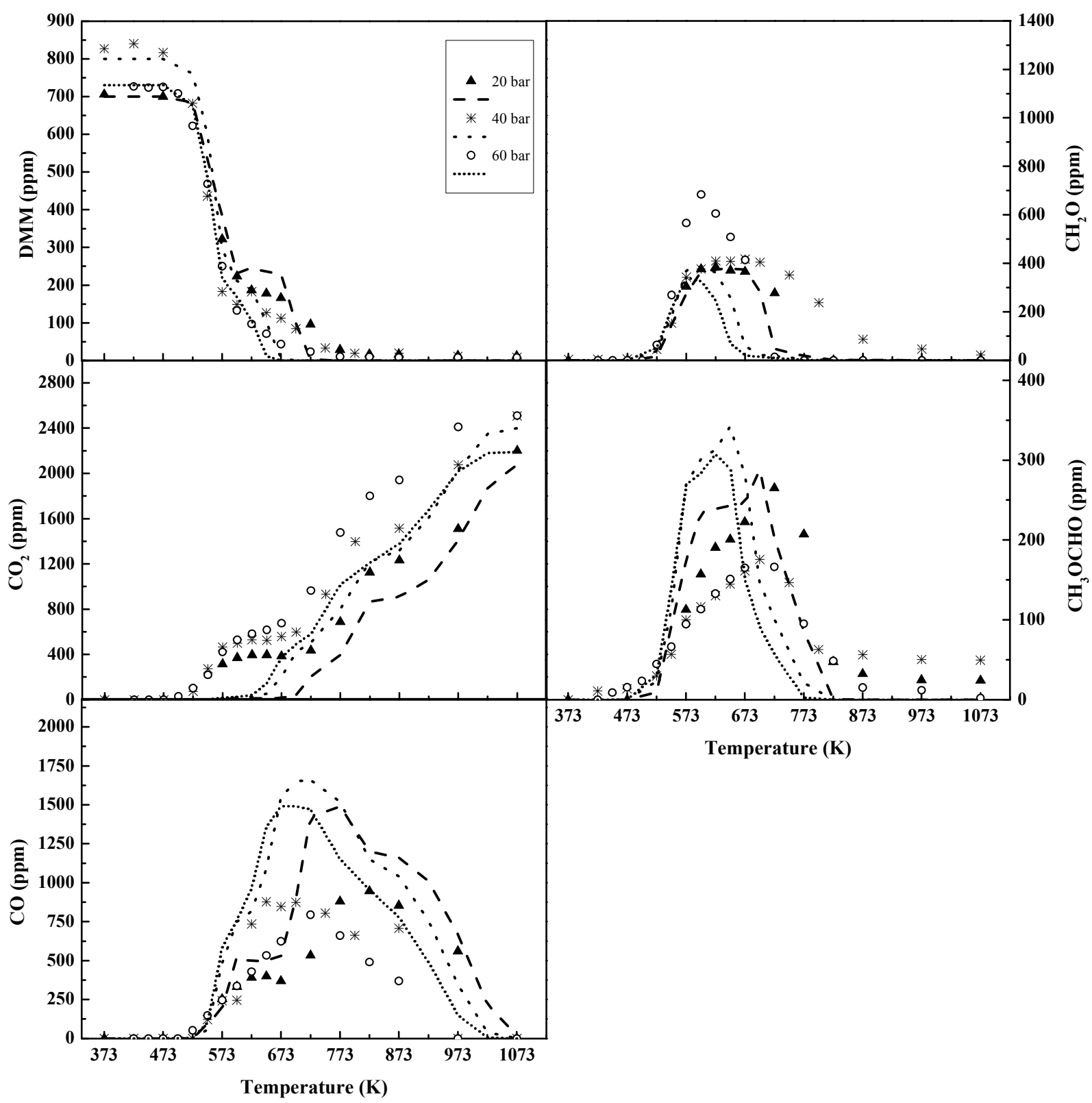

Fig. 4. Influence of pressure on the $\mathrm{DMM}, \mathrm{CO}_{2}, \mathrm{CO}, \mathrm{CH}_{2} \mathrm{O}$ and $\mathrm{CH}_{3} \mathrm{OCHO}$ concentration profiles as a function of temperature for a given air excess ratio $(\lambda=20)$. Sets $7-9$ in Table 1. 


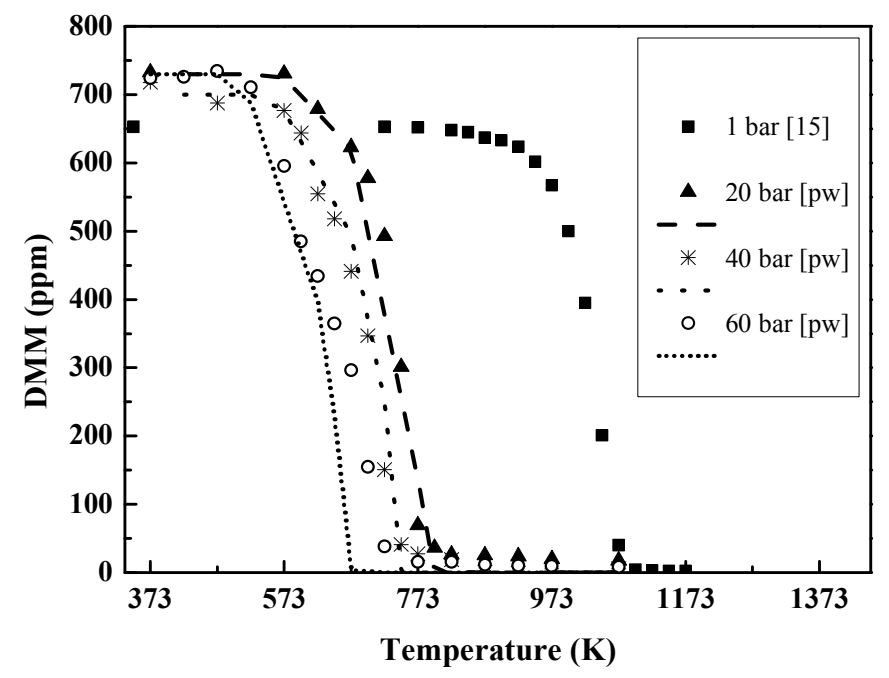

Fig. 5. Results for stoichiometric conditions, at 1 bar (experimental) from Marrodán et al. [15] and at high-pressure (experimental and modeling) from the present work [pw], sets 4-6 in Table 1. 

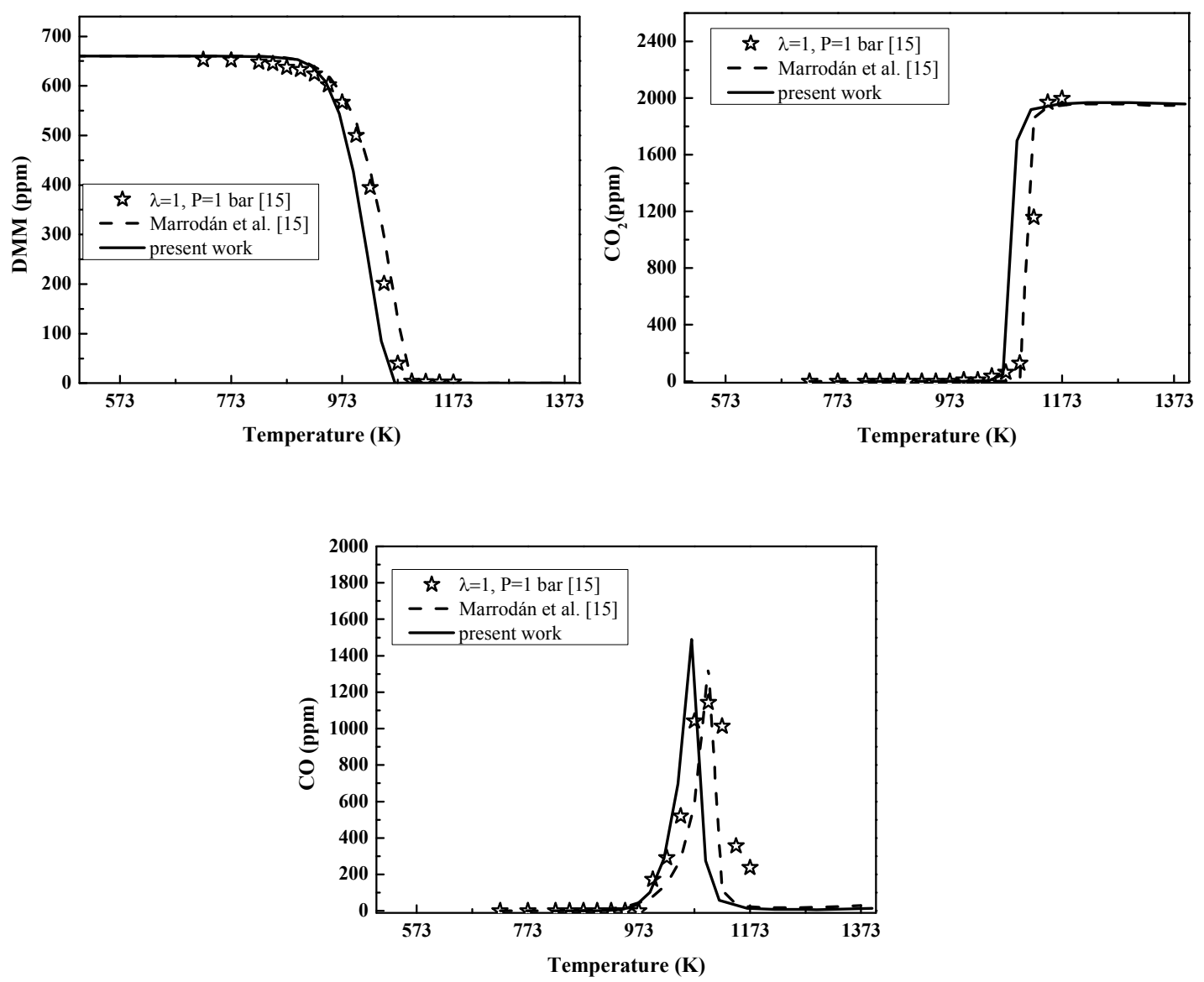

Fig. 6. Comparison (for DMM, $\mathrm{CO}$ and $\mathrm{CO}_{2}$ concentrations) between modeling calculations obtained with the initial mechanism [15] and the mechanism used in the present work for the experimental results obtained at atmospheric pressure and $\lambda=1$, for the conditions indicated in $[15]$. 


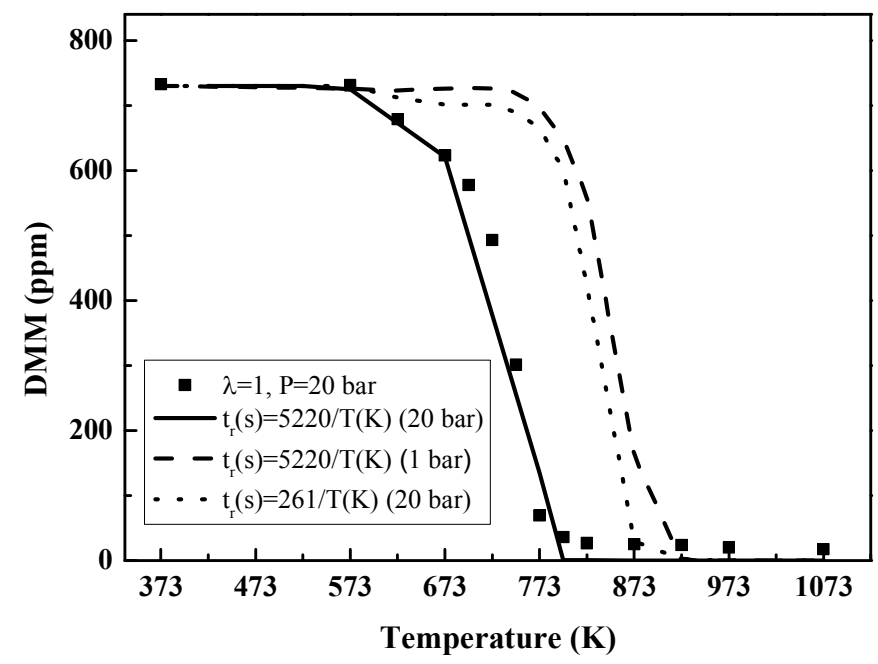

Fig. 7. Evaluation through model calculations of the effect of gas residence time (comparison between solid lines, $\mathrm{t}_{\mathrm{r}}(\mathrm{s})=5220 / \mathrm{T}(\mathrm{K})$, and short-dashed lines, $\left.\mathrm{t}_{\mathrm{r}}(\mathrm{s})=261 / \mathrm{T}(\mathrm{K})\right)$ and pressure (comparison between solid lines, $\mathrm{t}_{\mathrm{r}}(\mathrm{s})=5220 / \mathrm{T}(\mathrm{K})$, and long-dashed lines, $\mathrm{t}_{\mathrm{r}}(\mathrm{s})=5220 / \mathrm{T}(\mathrm{K})$ ) for a selected example under the conditions indicated in set 4 , Table 1. 